\title{
LOCALISATION OF UPPER OESOPHAGEAL FOREIGN BODIES IN A RECUMBENT TETRAPLEGIC PATIENT
}

\author{
By A. T. Scher, M.B., Ch.B., D.M.R.D. \\ Spinal Injuries Centre, Conradie Hospital, Cape Town, South Africa
}

Abstract. Report of oesophageal obstruction in a tetraplegic patient following swallowing of a chicken bone. Removal following x-ray localisation.

Key words: Oesophageal obstruction; Tetraplegia.

\section{Introduction}

THE frequent occurrence of fractures and dislocations in the cervico-dorsal region, together with the technical difficulties in radiographically demonstrating this region on the lateral view, have caused us to pay particular attention to the radiography of the area (Scher and Vambeck, 1977). In those patients who are of necessity X-rayed in the supine position, e.g. tetraplegics and hemiplegics, superimposition of the shoulders on the lower cervical region obscures not only the lower cervical and upper thoracic vertebrae, but also the soft tissue structures lying anterior to the vertebral column.

Particularly important are the oesophagus and trachea which commence at the level of the sixth cervical vertebra. The presence of a foreign body in the oesophagus of a tetraplegic patient recently referred to our department emphasises the necessity of good radiographic visualisation of both soft tissue structures and vertebral column in the lower cervical region, in all patients X-rayed in the recumbent position.

\section{Case History}

A 20-year-old female tetraplegic patient was referred to the X-ray department with a history of having swallowed a chicken bone three hours previously. She complained of pain and discomfort on swallowing. The patient localised the site of discomfort at the level of the thyroid cartilage.

At the age of 15 she had been involved in a motor vehicle accident, sustaining fractures to the vertebral bodies of $\mathrm{C}_{5}$ and $\mathrm{C} 6$, with resultant complete motor and sensory paralysis below the $\mathrm{C}_{5}$ level.

A horizontal beam view of the neck, with patient supine, failed to reveal any foreign body. An antero-posterior view also showed no evidence of a foreign body.

It was noted on the lateral view that visualisation of the lower cervical region was inadequate due to superimposition of the shoulders. The lateral view was therefore repeated with traction applied to patient's arms in order to clear the shoulder from the cervical region. This repeat view demonstrated the chicken bone in the cervical oesophagus; see Figure I. The patient was then taken to theatre for removal of the bone under general anaesthesia.

\section{Anatomy}

\section{Discussion}

The oesophagus arises from the pharynx at the cricoid cartilage opposite the sixth cervical vertebra and descends in front of the vertebral column to traverse 

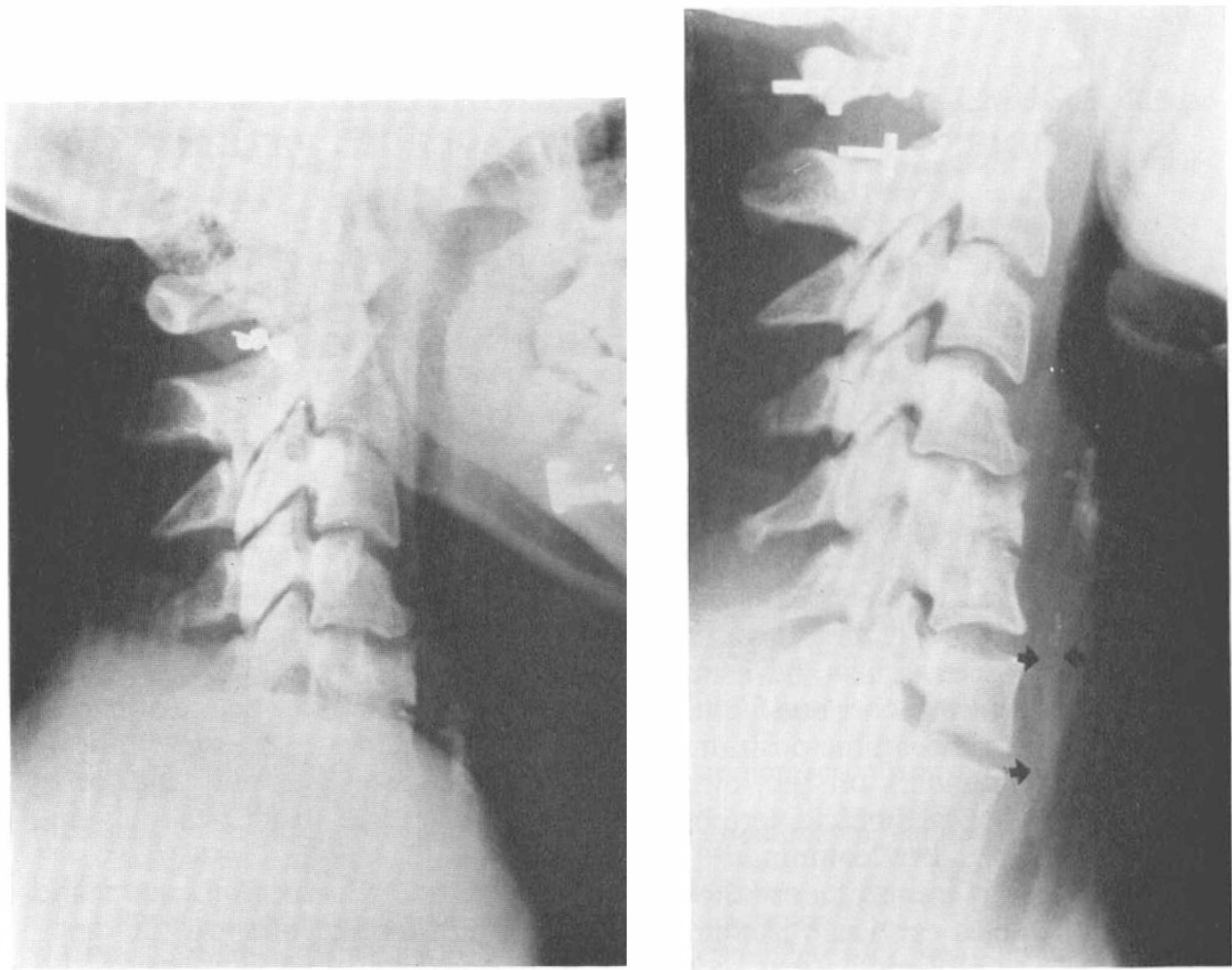

FIG. I

(a) (left). Standard supine lateral view. Lower cervical region not demonstrated. Calcified Thyroid cartilages are visible, but there is no evidence of any foreign body. Healed fractures of $\mathrm{C}_{5}$ and $\mathrm{C} 6$ are present.

(b) (right). 'Pulled' lateral view. The lower cervical region is well demonstrated. A long, narrow bone (arrowed) is present in the oesophagus.

the oesophageal opening in the right crus of the diaphragm at the level of the tenth thoracic vertebra and enters the stomach at the eleventh.

The oesophagus is the least dilatable part of the alimentary canal (an inch at the most) and is therefore easily blocked (Lockhart et al., 1959). There are three normal areas of narrowing in the oesophagus, its commencement, where it is crossed anteriorly by the left main bronchus and where it passes through the diaphragmatic hiatus.

\section{Foreign Bodies in the Oesophagus}

The most frequent site for oesophageal foreign bodies is the cervical oesophagus just below the cricopharyngeal constriction (Jackson and Jackson, 1959). The upper end of the oesophagus is closed by the cricopharyngeus muscle which opens during the act of swallowing to allow the food bolus to enter. This sphincterlike muscle will contract rapidly if a foreign body enters the oesophagus and the object is then held immediately below the muscle at the upper end of the oesophagus, where it may remain for some hours. Once a foreign body passes the 
upper end of the oesophagus it may be arrested at the hiatus or, less commonly, at the level of the crossing of the left bronchus.

In adults, fish or meat bones are the most usual objects which are swallowed. These are often retained in the pyriform fossa or they may be held up immediately distal to the cricopharyngeus, where they cause pain and dysphagia. Because of the relatively insensitive nature of the oesophagus, which only responds to the painful stimuli of scratching or stretching, localisation by the patient is poor (Maran, 1977).

\section{Radiographic Demonstration of Oesophageal Foreign Bodies}

There is a marked difference in the ease of radiographically demonstrating oesophageal foreign bodies in ambulant patients as compared to those who are perforce X-rayed in the supine position.

\section{The Ambulant Patient}

Technique: The examination commences with antero-posterior and lateral views of the neck with patient erect. For the lateral radiograph the patient is asked to pull the shoulders down, thus clearing the lower cervical region and affording visualisation of the soft tissue structures of the neck down to the level of the thoracic inlet. Where no radio-opaque foreign body is demonstrable, a barium swallow should be performed if clinically indicated. Attention is paid to any hold up of barium, deviation of the barium stream, spasm of the oesophagus or coating of a radiotranslucent foreign body with barium. Any of these observations may draw attention to the presence of a foreign body.

\section{The Supine Patient}

Technique: The radiographic examination, as described above, for ambulant patients is not easily accomplished in those patients who are unable to stand or voluntarily depress the shoulders. In 58 per cent of a series of tetraplegic patients recently examined (Scher and Vambeck, I977), the sixth cervical vertebra was the lowest visualised on the standard supine lateral radiograph of the cervical spine. Therefore in over half the patients examined the vertebral column and soft tissue structures of the cervico-dorsal region were not demonstrated on this view.

The commonest oesophageal foreign bodies, i.e. meat and fish bones, are usually long narrow objects. They therefore tend to lodge vertically, lying parallel to the long axis of the oesophagus. They are not often demonstrated on the antero-posterior view of the neck, as they do not lie tangential to the X-ray beam. Visualisation on the antero-posterior view is also impaired because the bones are similar in density and structure to the cervical vertebrae on which they are superimposed.

Barium swallow in the tetraplegic patient is, in our experience, best performed in the prone oblique position. However, even in this position the bones of the shoulder girdle obscure the upper oesophagus making visualisation of this area difficult.

The lateral view is therefore of particular importance in excluding the presence of radio-opaque foreign bodies in this group of patients. If the lower cervical region is not adequately demonstrated, it is suggested that a 'Pulled' lateral view (as described below) be obtained. This view which is technically easy, not time consuming and requires only one extra exposure, will demonstrate the lower cervical region in the majority of supine patients. 


\section{'Pulled' Lateral View}

Technique: The patient is supine with cassette placed against the lateral aspect of one shoulder. Both shoulders are pulled down by two assistants who stand on either side of the patient grasping the arms above the elbows and pulling them towards the feet. If this manoeuvre tends to pull the patient down the X-ray table, counter-traction should be applied to the head by using either a radiotranslucent halter, if available, or by stabilising the head with sandbags on either side. This counter-traction will serve to maintain the position of the head against the pull of the shoulders.

\section{Conclusion}

The commonest site for oesophageal foreign bodies is the cervical oesophagus. In over half the patients who are of necessity X-rayed in the supine position, the lower cervical region, and therefore the cervical oesophagus, will not be demonstrated on the lateral view. The antero-posterior view is not often helpful in the exclusion of the most usual foreign bodies (meat and fish bones), while barium swallow in the recumbent patient is a difficult procedure. Utilisation of the 'Pulled' lateral view will assist in the radiological exclusion of radio-opaque foreign bodies in those patients who are unable to be examined in the erect position.

\section{RÉSUMÉ}

L'oesophage cervical est l'endroit le plus fréquent d'obstruction par des corps étrangers de l'oesophage. L'importance de visualiser la partie cervicale inférieure lors de l'exclusion radiologique de corps étrangers dans l'oesophage est soulignée. Chez plus de $50 \%$ de patients soumis aux rayon $\mathrm{X}$ en position couché (a cause de leur incapacité de se tenir debout) la partie cervicale inférieure ne sera pas visible en vue latérale. L'usage d'une vue latérale 'en traction' pour obtenir une bonne image de l'oesophage parmi ce groupe de patients est recommandé. Un exemple historique illustrant la valeur de cette théorie est décrité.

\section{ZUSAMMENFASSUNG}

Der zervikale Oesophagus ist die am häufigsten betroffene Region einer Versperrung durch oesophageale Fremdkörper. Um das Vorhandensein oesophagealer Fremdkörper radiologisch auszuschliessen, wird die Wichtigeit der Darstellung der unteren zervikalen Region herausgestellt.

In $50 \%$ der Patienten die in Rückenlage geröntgt wurden (wegen ihrer Unfähigkeit zu stehen), wird die untere zervikale Region bei der Seitenansicht nicht erfasst werden. Es wird der Gebrauch der 'Pulled' Seitenansicht empfohlen, um eine gute Darstellung des Oesophagus bei dieser Patientengruppe zu gewöhrleisten.

Ein Fall wird beschrieben, um den Wert dieser Ansicht zu erläutern.

\section{REFERENCES}

Jackson, C. \& Jackson, C. L. (1959). Diseases of the Nose, Throat and Ear, W. B. Saunders, Philadelphia, p. 849.

Lockhart, R. D., Hamilton, G. F. \& Fyfe, F. W. (1959). Anatomy of the Human Body. Faber \& Faber, London, pp. 500-501.

Maran, A. G. D. (I977). In Logan Turner's Diseases of the Nose, Throat and Ear, ed. J. F. Birrell. John Wright \& Sons, Bristol, p. 220.

SCHER, A. T. \& VAMBECK, V. (I977). An approach to the radiological examination of the cervico-dorsal junction. Clinical Radiology, 28, 243-246. 